\title{
Squamous cell carcinoma of tongue in HIV patients- a report of 3 cases
}

\author{
SP Selvajothi Ranjitham*, K Gnanambigai, P Kamaleswari, Elizabeth Joshua, Umadevi K Rao, K Ranganathan \\ From 2nd International Science Symposium on HIV and Infectious Diseases (HIV SCIENCE 2014) \\ Chennai, India. 30 January - 1 February 2014
}

\section{Case series}

Oral manifestations of HIV disease are broadly classified as "strongly associated with HIV", "less commonly associated with HIV" and "can be seen in HIV infection". Malignancies reported in HIV infection include Kaposi's sarcoma, Non-Hodgkin's lymphoma and squamous cell carcinoma of the oral cavity. At our Ragas- YRG CARE center, in a cohort of 5760 cases which were screened, 6 patients of Non-Hodgkin's lymphoma and 4 patients with oral squamous cell carcinoma were reported. We present 3 cases of oral squamous cell carcinoma on the lateral border of the tongue with varied clinical presentations. A comparison of the demographic data, habits, HIV history, clinical presentation, investigations, histopathological diagnosis and treatment of the three cases were made; 2 patients had no history of tobacco use, suggesting role of factors such as HPV co infection.

Published: 27 May 2014

doi:10.1186/1471-2334-14-S3-E38

Cite this article as: Ranjitham et al:: Squamous cell carcinoma of tongue in HIV patients- a report of 3 cases. BMC Infectious Diseases 2014

14(Suppl 3):E38.
* Correspondence: spselvajothi@gmail.com

Department of Oral Pathology and Microbiology, Ragas Dental College, Chennai, India
Submit your next manuscript to BioMed Central and take full advantage of:

- Convenient online submission

- Thorough peer review

- No space constraints or color figure charges

- Immediate publication on acceptance

- Inclusion in PubMed, CAS, Scopus and Google Scholar

- Research which is freely available for redistribution 